\title{
Community attitudes and behaviour towards conservation: an assessment of a community conservation programme around Lake Mburo National Park, Uganda
}

\author{
Mark Infield and Agrippinah Namara
}

\begin{abstract}
This paper analyses the impact of a community conservation programme (CCP) implemented over a 7-year period around a national park in Uganda. Programme activities included dialogue, conflict reduction, education, community resource access and support for community development. Surveys of attitudes show that communities benefited from the programme were significantly more positive towards the park and wildlife than communities that did not. The community conservation programme built an understanding of conservation objectives amongst communities whose members were more likely to recognize positive aspects of the park and less likely to demand that it be degazetted. Comparison over the 7-year duration of the programme, however, did not show that communities were generally more positive towards conservation. They were more critical of management and demanded
\end{abstract}

more support and resources than they had received. Their behaviour was not greatly changed, and high levels of poaching and illegal grazing continued. Attitudes were influenced by communities receiving development assistance, but improvements were fragile, vulnerable to poor behaviour of park staff and lawenforcement activities. Both were seen as contradicting community approaches. Attitudes were also influenced by land ownership and economic occupation. The CCP was not a panacea for the problems of the park and did not resolve fundamental conflicts of interest between communities and park management. However, it did change the way the protagonists perceive and interact with each other.

Keywords Attitudes, community conservation, Lake Mburo National Park, protected areas, Uganda.

\section{Introduction}

Africa's protected areas are critical to the conservation of the continent's biological diversity (Ehrlich \& Daily, 1993; Robinson, 1995; Myers, 1996), if not alone sufficient to conserve it. As institutions, however, they are problematic. Of particular concern to conservationists is that the gazettment and management of protected areas often bring hardships to poor, rural communities living in or around them (Calhoun, 1991; Ghimire \& Pimbert, 1997). These result from lost economic opportunities and exclusion from protected area resources (Ghimire, 1991; Ghimire \& Pimbert, 1997), and from damage caused to farms and livestock by wild animals (Parry \& Campbell, 1992; Naughton-Treves, 1998). Contradictions between demands for increased production and economic security for Africa's rural poor, and the imperatives of wildlife conservation have led to its rejection by many communities living around protected areas (Abrahamson, 1983). Negative attitudes also result

Mark Infield (corresponding author) School of Development Studies, University of East Anglia, Norwich, NR4 7TJ, UK. E-mail: mark@infield.nu

Agrippinah Namara Makerere Institute of Social Research, Kampala, Uganda. E-mail: misrlib@imul.com

Revised manuscript accepted for publication 21 June 2000 from colonial approaches to conservation, which alienated communities from the wildlife resource through hunting licensing controls, establishment of exclusive protected areas and punitive policing (Mackenzie, 1987; Hackel, 1999).

Responding to perceptions of many conservationists especially those working in poorer countries - that wildlife conservation and protected areas were doomed unless local communities become an integral part of conservation efforts (Adams \& McShane, 1992; Hackel, 1999), new strategies, often referred to as 'community conservation' have evolved over the past two decades. Community conservation is intended to be inclusive rather than exclusive of local communities (Infield \& Adams, 1999). Early enthusiasm for such programmes has been tempered in recent years by a more critical examination of their impact on both conservation and development objectives (Noss, 1997; Lewis \& Phiri, 1998; Hackel, 1999; Hulme \& Murphree, 1999). Assessing the effectiveness of community conservation in supporting the conservation of biodiversity is necessary, if such programmes are to find support amongst protected area managers and be integrated into day-to-day management operations. An examination of the attitudes of communities towards protected areas provide a means of assessing such programmes, and is useful where 
assessing changes in behaviour is difficult, as is the case in examining poaching and other illegal activities. Although the attitudes of individuals are not always closely linked to their behaviour, community conservation programmes attempt to influence thinking and attitudes in the belief that this will lead to changes in behaviour. Though this assumption itself may need testing, examining the influence of community conservation programmes $(\mathrm{CCP})$ on attitudes provides a means to assess their impact.

This paper describes a CCP carried out around Lake Mburo National Park (LMNP) in south-western Uganda (Fig. 1) by an international NGO (African Wildlife Foundation, (AWF)) in collaboration with a national conservation authority (Uganda Wildlife Authority). Data are presented on activities carried out and on attitudes and behaviours of local people towards wildlife and the park. Analysis of changes in these that can be attributed to the CCP allow an assessment of the effectiveness of the programme and the approach taken.

\section{Background}

The LMNP was declared in 1983, although the area had formerly been a game reserve, and before that, a controlled hunting area. The decision to create a national park had conservation merits, and was supported by the international conservation community (Kingdon, 1985).

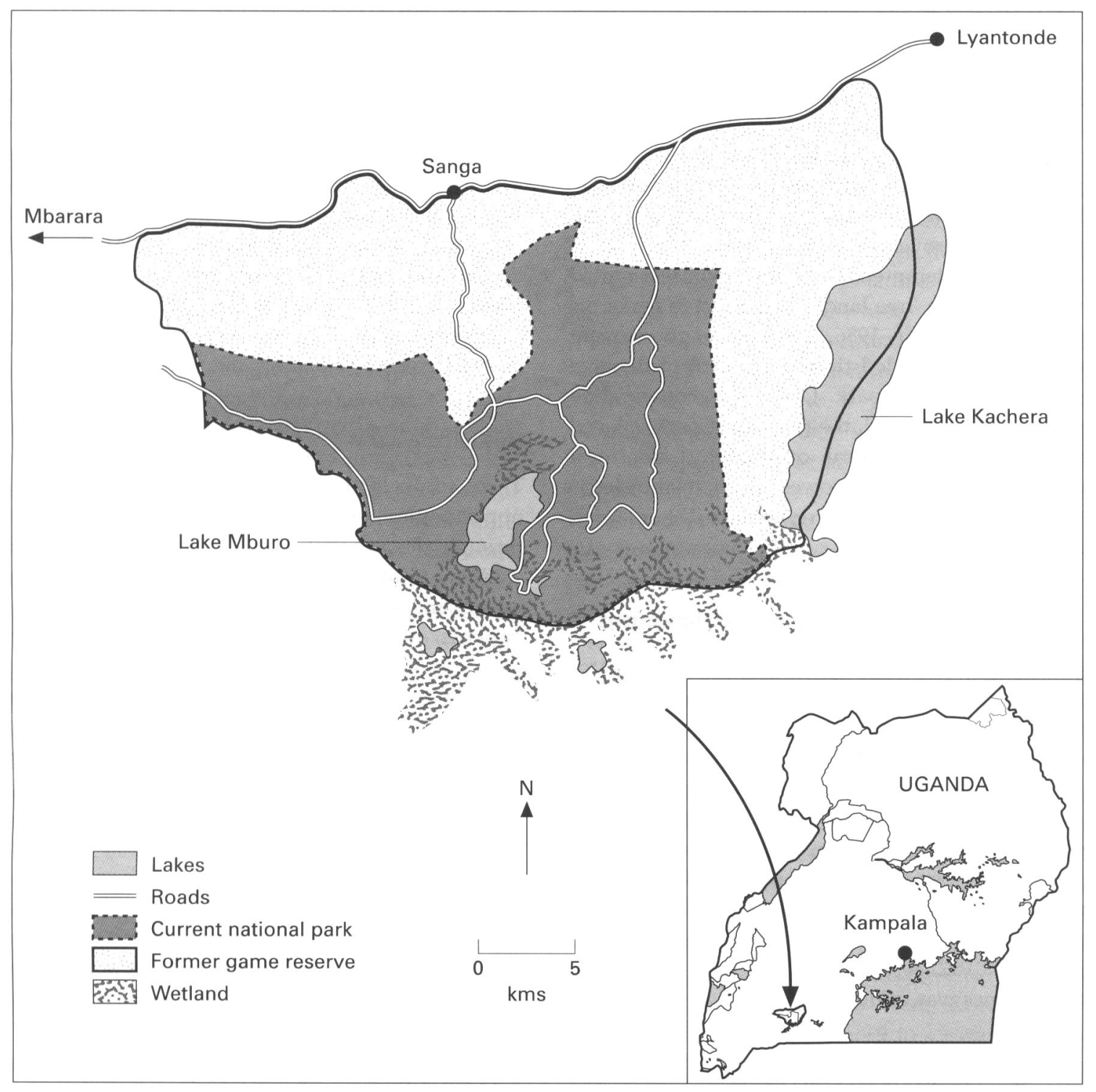

Fig. 1 Lake Mburo National Park and former Game Reserve boundaries. Inset shows Uganda with location of Lake Mburo National Park and the capital, Kampala. 
Although small (approximately $650 \mathrm{sq} \mathrm{km}$ at that time) the park conserved a representative example of the biologically-diverse interlacustrine ecosystem (van der Wegge, 1986), supported Uganda's only population of impala Aepyceros melampus, important populations of eland Taurotragus oryx and zebra Equus burchellii (Muhweezi, 1994), as well as several species of birds of regional or international conservation significance (Pomeroy \& Kasoma, 1992). It is apparent, however, that there were political motivations behind the declaration as well (Mugisha, 1993; Kamugisha et al., 1997). The park disadvantaged the Banyankole people, especially Bahima pastoralists, who were believed to hold antigovernment sentiments. Despite the presence of many farming and pastoralist households within the game reserve with government licences to reside there, all residents were summarily evicted. No effort was made to compensate dispossessed families. Not surprisingly, this action produced strong antipathy towards the new park (Kamugisha \& Stahl, 1993).

When the then government fell from power in 1985, the new government encouraged evicted families to return. The park was re-occupied, park staff driven off, infrastructure destroyed and systematic eradication of large mammals attempted. Returning evictees invited others to occupy the 'free land' in an effort to make the park unmanageable. In 1986, however, a government commission recommended that 40 per cent of the area be retained as national park. Despite its conservation value and tourist potential, the remaining park enjoyed the support of neither local communities nor local leaders. Its survival to date owes much to the determination and support of the President of Uganda, HE Yowori Kaguta Museveni.

\section{The community conservation programme}

Despite the allocation of 60 per cent of the park for agriculture and pastoralism, relations between park and community were typified by mutual hostility and suspicion (Marquardt $e t$ al., 1994). A project was designed to help reduce tensions and strengthen the park (African Wildlife Foundation, 1990, 1994). Park staff were supported to carry out a programme of activities to improve the relationship between the park and surrounding communities. A Community Conservation Unit, consisting of a warden and three specialist rangers, was established in 1992. A wide range of initiatives under six broad themes was undertaken.

\section{Establishing a dialogue with communities}

Initially relations were so hostile that simply getting local people and park staff to interact was necessary.
Conflict reduction was an important goal. To assist in this, over 135 community meetings, and 150 meetings with local leaders and other interested parties were held between 1991 and 1994.

\section{Conservation education programmes \\ for local schools and adult groups}

This included development of a residential education facility in the park, the facilitation of local school and adult groups to visit the park, and teaching about the park and conservation in local schools. Over 12,500 students and adults were reached at least once between 1991 and 1997.

\section{Joint funding of community initiated microdevelopment projects}

Approximately $\$ U S 75,000$ was invested in 15 social infrastructure and seven revenue-generating projects. These funds were intended primarily, to promote conservation and tourism-related enterprises. An important aspect of CCP was to demonstrate that the park could provide tangible economic benefits (African Wildlife Foundation, 1990). However, community priorities were different, and led to 91 per cent of the funds being spent on constructing or improving social infrastructure, especially primary schools and health facilities.

\section{Resource access}

The CCP helped establish procedures for providing opportunities for community access to park resources through the negotiation of Memorandums of Understanding (MoUs). The MoUs developed included access to lake and swamp fish ( $3 \mathrm{MoUs}$ ), water (4 MoUs), and papyrus and medicinal plants (2 MoUs). Emergency access to grazing and water in response to extended drought and disease outbreaks was also arranged. Mechanisms for monitoring the implementation of agreements were developed.

\section{Reducing wildlife-caused crop damage}

Live fencing was promoted through exposure and training of groups of farmers and providing seeds and seedlings. Local government problem animal-control procedures were established and supported through training and reviewing exercises.

\section{Support for community institutions}

A Park Management Advisory Committee was supported to allow representation of local concerns to park 
authorities. The committee was closely involved in establishing procedures for resource access and was the primary vehicle for allocating $\mathrm{CCP}$ funds to community projects.

The project also supported training and study tours for park staff and community members, lobbied on behalf of the park, established political contacts, and supported relevant local and national government programmes.

Project support to the CCP comprised provision of vehicles and equipment, training of staff and community members, operating costs including salary supplements and allowances, and technical support. Although not large in terms of development aid terms (expenditure averaged approximately $\$ U S 300,000$ per annum (African Wildlife Foundation, 1990, 1994), the level of activities supported was greater than could be sustained independently by the Uganda Wildlife Authority (Hulme \& Infield, 1998).

\section{Assessing impact}

In 1991-1992 and 1996-1997, surveys of community attitudes and behaviour towards the park were undertaken. The 1996-1997 survey was designed to allow comparison with baseline data collected in 1991-1992. The sample was stratified into communities that had experienced intensive programme activities (focus areas) and communities that had not (non-focus areas). Although between 1991 and 1997, CCP activities were carried out in all parishes around the park, the level of contact with communities was not equal. The level of CCP activities carried out in a community was influenced by the severity of problems perceived by communities to be caused by the park, and vice versa. Communities where problems were greatest thus tended to receive greater attention, though accessibility was also a factor. Until 1995, however, little work with pastoralist communities was undertaken as government plans to resettle them were pending. The pastoralists also found it difficult to participate actively in CCP because they were unsure where they would be settled finally (Marquardt et al., 1994). Five communities covered in the 1991-1992 survey were replicated in the 1996-1997 survey, three of which were 'focus area' communities. Both surveys used formal questionnaires made up of open and closed response questions administered by trained enumerators. A rapid rural appraisal, key informant interviews and other qualitative methods were employed to provide supporting information for a deeper analysis of questionnaire data. Details of survey methods and results may be found in Marquardt et al. (1994) and Namara et al. (1998). Data presented in this paper have been analysed using chi-square $\left(\chi^{2}\right)$ tests.
The first author, MI, was the technical advisor to both projects and designed the surveys. The coauthor, AN, implemented the surveys and was closely involved in data analysis.

\section{Results}

\section{Community attitudes toward the park}

Respondents in the 1996-1997 survey were presented with an open question, 'What are your feelings about Lake Mburo National Park?' Forty per cent gave responses suggesting that it was good to conserve wildlife whereas 15 per cent believed that the park should be abolished. A further 11 per cent felt that the park was a waste of land. A similar question was put during the 1991-1992 survey. Although not directly comparable (the 1991-1992 survey was looking at knowledge rather than attitude), the results showed that 41 per cent of respondents felt it was important to conserve wildlife, 15 per cent thought the park was a waste of land and another 10 per cent indicated that the park was damaging the interests of their community. These very similar results suggest that there was little change between 1991 and 1992 and 1996-1997 surveys across the community as a whole.

Table 1, however, shows clear differences in responses between $\mathrm{CCP}$ focus and non-focus areas. Respondents from focus areas show a generally more positive attitude, in particular they were less likely to suggest that the park should be abolished and more likely to suggest that 'it can be good to conserve wildlife'. In places where intensive work was carried out, the programme appears to have convinced many respondents that the park performed a function in conserving wildlife. Similar results were found in responses to a closed question asking directly 'Should the park be abolished?' ( $\chi^{2}$ test: $\left.P=0.0001\right)^{1}$. Three-quarters of respondents in focus areas rejected the idea compared with just half in non-focus areas (Namara et al., 1998).

Attitudes were also examined using statements with which respondents were asked to agree or disagree (Table 2). Responses were scored and used to place respondents on an index of attitude towards conservation. Agreement with a positive attitudinal statement was scored +1 whereas disagreement was scored -1 . Similarly, agreement with a negative attitudinal statement was scored -1 whereas disagreement was scored +1. 'Don't know' responses were scored zero. The potential scoring range from -9 to +9 was divided into

\footnotetext{
${ }^{1}$ This closed question was not put to respondents during the 1991-1992 survey as park officials felt it was too controversial, so no comparison over time can be made.
} 
Table 1 Reported feelings of respondents towards the park.

\begin{tabular}{lll}
\hline Feelings expressed & $\begin{array}{l}\text { CCP focus areas } \\
\%(n=325)\end{array}$ & $\begin{array}{l}\text { CCP non-focus } \\
\text { areas } \%(n=99)\end{array}$ \\
\hline Good to conserve wildlife & 44.3 & 27.3 \\
Should allow resource access & 14.5 & 17.2 \\
Waste of land & 10.8 & 11.1 \\
Should be fenced & 6.5 & 5.1 \\
Benefits local people & 4.3 & 2.0 \\
Should be abolished & 12.0 & 26.3 \\
Other & 2.2 & 2.0 \\
None & 5.5 & 9.1 \\
\hline
\end{tabular}

$(P=0.00913)$

Table 2 Statements used to formulate index of attitudes towards conservation.

Statements

What people and their livestock need is more important than protecting wild animal and plants ${ }^{a}$

It is important to protect animals and plants so that our children can see and use them in future ${ }^{b}$

The tourists who come to the area are useful to the people $\mathrm{e}^{b}$ The government made the park to take our land and keep us poor ${ }^{a}$ People should be allowed in the park to farm and graze animals as they wish

Parks are a waste of land in Uganda when people are short of land ${ }^{a}$ It is important to set aside a place for plants and animals to live in $^{b}$ Grazing and farming should be prevented in the park, or else all the animals will disappear ${ }^{b}$

People should be allowed to eat game meat. Why keep animals we cannot eat ${ }^{a}$

${ }^{a}$ Negative attitudinal statement.

"Positive attitudinal statement.

a five-category index of attitude towards conservation and the park; 'very negative' -9 to -6 ; 'negative' -5 to -2 ; 'neutral' -1 to +1 ; 'positive' +2 to +5 ; and 'very positive' +6 to +9 . Comparing 1991-1992 and 1996-1997 results for the CCP area shows no significant differences in attitudes (Table 3 ). Comparing just the communities replicated in the survey found that respondents who scored 'negative' or 'very negative' actually increased by 15 per cent whereas respondents who scored as 'positive' or 'very positive' fell by the same amount (Namara et al., 1998). These results suggest a failure of the CCP to build positive attitudes. They may, however, reflect a sampling anomaly. Communities randomly selected for replication contained disproportionate numbers of landless pastoralists. Both landless households and pastoralists are more likely than other groups to hold negative attitudes towards the park (Tables 4 and 5). Pastoralist communities enjoyed less support from CCP than others, and often indicated resentment towards the park for not including them more often. However, pastoralists were also found to be more negative towards the park in the 1991-1992 survey (Marquardt et al., 1994).

Table 3 shows that comparison of scores of respondents from focus and non-focus areas have significant differences. A third of respondents from focus communities were scored as 'very positive' towards conservation, compared with only 13 per cent from non-focus communities. Respondents scored as 'very negative' were 14 and 38 per cent, respectively. As discussed earlier, focus areas were concentrated on by the CCP partly because relations with them were particularly difficult. This result suggests therefore that intensive community extension work can produce significant improvements in community attitudes.

\section{Community perceptions of the park}

Attitudes are formed in part by communities' and individuals' perceptions and experiences of the park. This is inevitably influenced by the behaviour towards local communities of rangers and wardens responsible for park management. Although efforts to influence this behaviour and underlying attitudes was part of CCP, assessing park staff attitudes towards communities and community approaches to conservation was not part of this research.

When questioned about the benefits of living near the park, over a quarter of respondents from focus areas referred to the support provided by the park for community projects compared with just 1 per cent from non-focus areas (Table 6). A further quarter (24.6 per cent) of respondents in focus areas indicated that

\begin{tabular}{lllll}
\hline $\begin{array}{l}\text { Attitude } \\
\text { index }\end{array}$ & $\begin{array}{l}1991-1992 \\
\%(n=243)\end{array}$ & $\begin{array}{l}1996-1997 \\
\%(n=378)\end{array}$ & $\begin{array}{l}\text { CCP focus area } \\
\%(n=292)\end{array}$ & $\begin{array}{l}\text { CCP non-focus area } \\
\%(n=87)\end{array}$ \\
\hline Very negative & 16.5 & 19.3 & 13.7 & 37.9 \\
Negative & 18.1 & 17.4 & 16.1 & 21.8 \\
Neutral & 16.5 & 15.6 & 14.4 & 19.5 \\
Positive & 20.6 & 18.7 & 21.9 & 8.0 \\
Very positive & 28.4 & 28.9 & 33.9 & 12.6 \\
\hline \multicolumn{2}{c}{$(P=0.90717)$} & $(P=0.00001)$
\end{tabular}

Table 3 Attitude index scores. 
Table 4 Influence of land ownership on attitudes towards the park (1996-1997).

\begin{tabular}{llll}
\hline \multirow{4}{*}{$\begin{array}{l}\text { Attitude index scores }(\%)(n=377) \\
\text { own land? }\end{array}$} & Negative & Neutral & Positive \\
\cline { 2 - 4 } Yes & 29.4 & 15.2 & 55.4 \\
No & 69.1 & 17.6 & 13.3 \\
\hline \multicolumn{4}{c}{$(P=0.00001)$} \\
\end{tabular}

Table 5 Influence of occupation on attitude index scores (1996-1997).

\begin{tabular}{llll}
\hline & \multicolumn{2}{l}{ Attitude index scores $(\% n=372)$} \\
\cline { 2 - 4 } & Negative & Neutral & Positive \\
\hline Cultivator & 29.4 & 13.7 & 56.8 \\
Cattle keeper & 52.4 & 22.0 & 25.6 \\
Mixed farmer & 37.7 & 15.1 & 47.4 \\
\hline
\end{tabular}

$(P=0.00001)$

Table 6 Reported benefits of living near LMNP.

\begin{tabular}{lcc}
\hline $\begin{array}{l}\text { Benefit of living } \\
\text { near LMNP }\end{array}$ & $\begin{array}{l}\text { CCP focus areas } \\
\%(n=325)\end{array}$ & $\begin{array}{l}\text { CCP non-focus } \\
\text { areas } \%(n=90)\end{array}$ \\
\hline Provides water/grazing & 5.2 & 2.2 \\
Supports development projects & 26.1 & 1.1 \\
Access to park resources & 4.3 & 5.6 \\
Nothing & 48.6 & 82.2 \\
Can see wildlife & 4.9 & 2.2 \\
Provides employment & 3.1 & 0.0 \\
Don't know & 0.6 & 1.1 \\
Other & 7.1 & 5.6 \\
\hline
\end{tabular}

$(P=0.00001)$

they benefited from the park in various ways (all positive responses summed) compared with only $\mathbf{1 5 . 6}$ per cent in non-focus areas. These results suggest that where benefits from the park were provided through the programme, they were actually recognized as benefits by communities. Furthermore, they were sufficient to demonstrate to half the respondents that the park had something to offer them. The programme thus built the perception in communities that the park provides benefits. However, that half the respondents in focus areas continued to see no benefits from living near the national park, despite the high level of CCP inputs, is noteworthy. This result may reflect the fact that the level of benefits received from the programme was low compared with the costs levied on communities by the park (Emerton, 1998; Hulme \& Infield, 1998). However, Parry \& Campbell (1992) also found that communities failed to recognize the actual benefits accruing to them from wildlife, although they were considerable. That respondents were primarily interested in the development contributions made to their communities by the CCP, rather than support for conservation or providing access to resources, is also important. It suggests both the difficulty of engaging communities in conservation rather than development issues, and the effectiveness of supporting community development as a means to building positive community-park relations.

Damage to crops and livestock caused by wildlife influences perceptions of the park, creates negative attitudes and probably influences behaviour also (Marquardt et al., 1994). This has been found to be the case elsewhere (Infield, 1988; Parry \& Campbell, 1992; Naughton-Treves, 1998). The perception or experience of other negative aspects of a park and its management are also likely to lead to negative attitudes. Despite $\mathrm{CCP}$ initiatives, the reporting by respondents of problems caused by wild animals rose from 80 per cent in 1991-1992 to 91 per cent in 1996-1997 (Namara et al., 1998). This probably reflects the intensification of land use and especially crop production in the area. Uganda Wildlife Authority responses, in both policy and practical terms, and the efforts of the CCP, have clearly been unable to deal with the issue. The increased reporting of problems may also reflect improved park-community relations, with respondents feeling freer to report their problems with wildlife than during the 1991-1992 survey.

Promotion of live fencing using Mauritius thorn Ceasalpina decipetala was only marginally successful, despite its demonstrated effectiveness in keeping wild animals out of cultivated fields around the park. Difficulties caused by labour requirements for hedge establishment and maintenance, and competition for space and water between the hedge and crops, made the use of Mauritius thorn more appropriate for groups than for individuals. The low level of co-operation within most of the communities around the park prevented the effective establishment of group hedges. Procedures for reporting wildlife damage were found to be confusing and responses by park staff ineffective. Current legislation prohibits local people from dealing themselves with wildlife that is causing problems (although they often do, by hunting them, especially in the case of baboons Papio anubis and bush pigs Potamochoerus porcus). The fact that legislation also does not allow for compensation for crop or livestock losses, leads to tacit or active support for poaching (Namara et al., 1998).

The reporting by respondents of other problems related to living near the park rose significantly from 11 per cent in the 1991-1992 survey to 35 per cent in the 1996-1997 survey $(P=0.00001)$. Changes also occurred in the pattern of problems reported (Table 7). That 
Table 7 Reported problems of living near LMNP.

\begin{tabular}{lcccc}
\hline Problems of living near park & $\begin{array}{l}1991-1992 \\
\%(n=25)\end{array}$ & $\begin{array}{l}1996-1997 \\
\%(n=87)\end{array}$ & $\begin{array}{l}\text { CCP focus areas } \\
\%(n=147)\end{array}$ & $\begin{array}{l}\text { CCP non-focus areas } \\
\%(n=52)\end{array}$ \\
\hline Ranger harassment & 0 & 37.9 & 33.3 & 51.9 \\
Land shortages & 0 & 20.7 & 12.2 & 1.9 \\
No resource access & 0 & 9.2 & 29.3 & 13.5 \\
Harsh park laws & 76.0 & 16.1 & 5.4 & 7.7 \\
Insecurity & 0 & 9.2 & 5.4 & 1.9 \\
Other & 24.0 & 6.9 & & \\
\hline
\end{tabular}

respondents were more prepared to report their perception of the park as problematic in 1996-1997 may reflect a greater confidence in criticising the authorities and the generally more relaxed relationship with the park authorities. The greater range of problems referred to may also indicate a wider knowledge of the park than existed in 1991-1992. Perceptions of 'harassment' by rangers persist despite CCP activities. However, fewer respondents from focus areas reported this than respondents from non-focus areas. Ranger harassment was most commonly reported in connection with conflicts over resources, especially grazing, water, fish and game meat. What the communities experience and describe as 'harassment', however, often refers to the enforcement of park by-laws by rangers. It is interesting that respondents from focus areas were more likely to complain about 'harsh park laws' than about 'harassment'. This suggests that the programme has led to a greater understanding, if not necessarily greater acceptance, of park by-laws and the relationship between laws and the role of rangers as law enforcers. Respondents from focus areas seemed better able to differentiate between the enforcement of by-laws, however unfair they were felt to be, and the behaviour of rangers, otherwise often interpreted as that of individuals acting in their own interests. Separating the functions and agendas of the state from those of the individual implementing government policy is often difficult in Uganda because of the way government resources were 'individualized' during the 20 years of political and economic chaos experienced in the country. However, differences in attitudes of rural communities towards conservation and the body responsible for conservation have been noted elsewhere (Infield, 1988; Fiallo \& Jacobson, 1995). Communities have been found to be more negative to the implementing staff or authority than to the activity of conserving wildlife itself. Parry \& Campbell (1992) actually found that meetings and discussions with conservation authorities led communities to develop 'a more negative attitude towards wildlife' rather than the presumed intention of improving attitudes through increased contact and dialogue.
Respondents from focus areas were more likely to cite lack of access to park resources as a problem. Allowing limited access to certain resources seems to have set a precedent as far as communities are concerned by demonstrating that the park authorities can agree to demands for resources. The resources provided have been insufficient to meet community demands or expectations or to significantly improve the economic situation, and seem to have stimulated demands for the provision of access to resources rather than diminish them.

\section{Demographic factors}

The fact that demographic variables can be predictors of attitudes towards the park is shown in Tables 4 and 5 . Relationships between support for conservation and respondents' education, wealth and receipt of benefits have been found elsewhere (Infield, 1988; Fiallo \& Jacobson, 1995). The 1991-1992 survey found relationships between tribe, economic activity, wealth in land and period of residence to be related to attitudes towards the park and natural resources (Marquardt et al., 1994). Awareness of these relationships is important in terms of designing CCPs and assessing the effects of external factors. The high rates of immigration into the area found in 1991-1992 have decreased (Table 8). In 1991-1992, almost 10 per cent of the population had been resident for less than a year, a quarter between 1 and 5 years, totalling almost a third of the population having been resident for $\geq 5$ years. In 1996-1997, only a

Table 8 Duration of residence in the area around LMNP.

\begin{tabular}{lll}
\hline Period of residence (years) & $\begin{array}{l}1991-1992 \\
\%(n=238)\end{array}$ & $\begin{array}{l}1996-1997 \\
\%(n=377)\end{array}$ \\
\hline $0-1$ & $9.2\}$ & -1 \\
$1-5$ & $23.5\} 32.7$ & $23.6\} 23.6$ \\
$6-10$ & 18.5 & 25.7 \\
Over 10 & 48.7 & 50.7 \\
\hline
\end{tabular}

$(P=0.01869)$ 
quarter of respondents had been resident in the area for $\geq 5$ years. In 1991-1992, the availability of farming land was responsible for attracting many of the immigrants (Marquardt et al., 1994). Closure of the agricultural frontier in the early 1990s, when all remaining common land was allocated to individuals, meant that land around the park had to be purchased, excluding many would-be immigrants. This would seem to be a positive thing for the park and conservation because fewer socially and economically vulnerable families will be easily able to settle around the park.

Significant changes in economic activities were also recorded between 1991-1992 and 1996-1997 (Table 9). Households practising 'pure' cattle keeping decreased, whereas households engaged in cultivation and 'mixed farming' increased. Pastoralist households have responded to the privatization of communal grazing lands and pressures for the adoption of sedentary production systems by growing crops as well as keeping cattle. Continued, if reduced, immigration by cultivators has also shifted the balance of economic activities around the park towards farming. These changes are of concern to the park. Although cultivators tended to be more positive towards the park than pastoralists, cultivation is generally less compatible with the conservation of large mammals than is pastoralism, and by fragmenting and converting natural or seminatural vegetation to farm land, has a generally negative effect on biological diversity and wildlife populations around the park.

A reduction in peripheral or secondary economic activities such as petty trading, brewing and charcoal burning ('other' in Table 9) was also recorded. Increases in mainstream economic activities and reductions in the number of households engaged in marginal economic activities indicates growing social and economic stability. The trend may also reflect the evolution of long-term economic strategies resulting from greater security of land tenure (Noss, 1997).

Table 9 Changes in economic activities

\begin{tabular}{lll}
\hline & $1991-1992$ & $1996-1997$ \\
Economic activity & $\%(n=151)$ & $\%(n=140)$ \\
\hline Cultivation & 25.8 & 37.9 \\
Cattle keeping $^{a}$ & 46.4 & 30.7 \\
Mixed farming $^{a}$ & 19.2 & 30.7 \\
Other & 8.6 & 0.7 \\
\hline
\end{tabular}

${ }^{a}$ Mixed farming category refers to households that cultivate and keep cattle, both carried out as largely independent land uses rather than as a farming system based on complex interactions between the two.

\section{Discussion}

The community conservation programme was implemented in an effort to influence the attitudes and behaviour of people living around LMNP, strengthening their support for wildlife conservation and the protected area. Although Hulme \& Murphree (1999) outline the difficulties of assessing changes in attitudes and attributing them to specific interventions, the programme carried out around LMNP does seem to have influenced perceptions and attitudes.

The programme appears to have achieved considerable success in improving relations between the park and local communities. Communities that experienced programme activities were, in general, more positive towards the park, held stronger perceptions of its values, and were more willing to see it remain as a park. A better understanding of the relationship between park by-laws and the behaviour of park rangers also seems to have been achieved. Although numerous problems remain, a degree of positive relations has been achieved, reflected in the steady improvement of interactions between park staff and communities. Other studies carried out around LMNP confirm this impression (Kazoora \& Victurine, 1997; Ratter, 1997; Hulme \& Infield, 1998).

The CCP undertook a wide range of activities, especially in its early years. The effect of the different activities cannot be separated and any impact measured can only be attributed to the CCP as a whole. Hulme \& Infield (1998) suggest that the progress made may be attributed to the shift towards a more conciliatory approach to park management. Ratter (1997) believes that the financial contributions made towards community projects had been important, while the conservation education programme appears to have increased the understanding and awareness of conservation issues (Namara et al., 1998). Senior park staff indicated that the most important element of the programme had been the demonstration that park authorities were genuinely committed to developing a more positive way of relating to local communities, although this was not always clearly reflected in the behaviour of staff on the ground.

Interpretation of results showing changes in community attitudes must be made with caution. Attitudes can be volatile and certain events can have strong, shortterm influence over them. Experience of benefits (the park renovating a community clinic, for example) can boost support for the park, cloaking negative attitudes, but this effect does not necessarily persist. Likewise, a single incidence of negative behaviour by park staff can sour relations with a community for months or even years. Work undertaken elsewhere also suggests that the 
existence of fundamental and unresolved conflicts make it difficult to improve relations between the park and community, despite implementation of programmes aimed at doing so (Scott, 1998). This emphasizes the importance of a long-term approach to modifying park and community interactions. It also makes clear the value of training park staff and efforts to change social and institutional norms of behaviour. The relationship between behaviour and attitudes might be unclear, but it is certain that ultimately CCPs must aim to change the behaviour of both communities and park management staff (Byers, 1996).

Significant changes were found to be taking place within communities surrounding LMNP. Immigration has reduced and households are engaging in mainstream economic activities such as farming and livestock husbandry rather than brewing beer or charcoal burning. Immigrants to the LMNP area were found to be less likely to recognize resource degradation, more likely to practice bush burning, and more likely to view the park as a problem (Marquardt et al., 1994). Communities with high number of immigrants and short-term residents rely more heavily on direct use of natural resources, tend to have short-term subsistence economic strategies, are less socially cohesive and are likely to lack a conservation ethic (Noss, 1997). As communities stabilize further, park authorities should be able to make easier progress in the establishment of positive relations with communities.

Increased social stability and reduced mobility of pastoralists also concerns park management. Sedentary farming is leading to a steady intensification of land use and crop production around the park. Although increased agricultural production is both inevitable and should contribute to reduced poverty in communities around the park, it will also increase conflict, especially with respect to problem animals. Furthermore, the trend from cattle rearing towards agriculture and the intensification of cattle rearing will eventually reduce rangeland available to wildlife outside the park by processes of habitat fragmentation and conversion. This may result in some loss of biological diversity and will certainly interrupt seasonal movements of large mammals in and out of the park, reducing the viability of some populations such as the eland (Guard, 1993). It is also likely to prevent the future development of wildlifebased industries compatible with conservation.

The CCP did not successfully find means to provide tangible benefits to communities in a way that directly supported conservation objectives. Most of the programme's community development funds were spent on social infrastructure projects. Although an indirect, longterm effect on conservation objectives can be argued, especially for support to schools, this is tenuous. Com- munity development priorities, finding expression through the participatory processes employed by the programme, led to a general failure in the establishment of conservation-enhancing community microdevelopment projects. For example, where conflicts existed over access to water, provision of a water dam was appreciated by the community in terms of development and removed the source of conflict. Very few such projects were funded, however, because community priorities lay elsewhere. Although hardly surprising, that the respondents' perceptions of the park are significantly based on its support for social development, also raises concerns for the CCP. Expenditure on development for conservation purposes does not necessarily give results that are effective in conservation terms (Adams \& Thomas, 1996) and community development needs are often directly contradictory to conservation (Wells, 1995; Noss, 1997). Similar observations have been made elsewhere. In Zimbabwe's CAMPFIRE communities, for example, revenues earned from wildlife conservation are invested in the expansion of agriculture and animal husbandry, undermining conservation objectives (Murombedzi, 1999). Despite the importance of supporting activities perceived by communities as priorities, it is evident that programmes intended to achieve conservation objectives must review strategies intended to promote participation and inclusion of communities so that conservation objectives are also met. Mechanisms that have proved their worth in the context of development initiatives may not always be transferable to projects which have conservation as their primary objective.

Access to park resources remains a contentious issue. Although procedures for negotiating access could be made simpler and faster, park management must be realistic about both their and the communities' capacity to regulate access and monitor impacts on conservation objectives. The fact that access to resources agreed to by park management appears to have raised expectations rather than defuse demands, is a matter of concern. Demand for resources that the park is unwilling to provide, especially grazing, have also strengthened. Fishing in lakes within the park provides a case in point. Lake Mburo supports a productive fishery that yields a catch worth over \$US100,000 per annum (Busulwa, 1996). The negotiation of a MoU to formalize the fishing industry on Lake Mburo has stimulated demands for access to other small lakes within the park, which the authorities wish to remain unfished for conservation purposes. Making the largest lake available for fishing has not reduced the demand for access to the smaller lakes and may indeed have encouraged communities to think in production terms, discounting the park's conservation objectives. Park authorities will need to find ways to divorce willingness to negotiate access to 
resources from community perspectives that resource use should be maximized.

It is perhaps inevitable that conflict over resources will remain, because it derives from an apparently irresolvable conflict of interest between the demands of conservation, and the economic needs and demands of local people. Most community members evidently see the park as unnecessarily large, and consumptive use of resources as unproblematic. Park authorities hold the opposite view. This fundamental conflict of interest and perception is unlikely to be resolved, community conservation programmes notwithstanding, unless perceptions and experience of poverty and land shortage by communities are reduced. For conservationists, the bottom line for protected area management will remain conservation whereas communities will continue to pursue development objectives, even when these conflict with conservation.

Modifying the behaviour of park staff towards local communities has not proved easy. Although law enforcement protectionist approaches have been complimented with efforts towards conciliation, consultation and participation, the attitudes and behaviour of many rangers towards community members remain negative. A coercive military culture continues to dominate (Ratter, 1997; Hulme \& Infield, 1998), as is the case generally in Uganda (Namara, 1998) and elsewhere (Peluso, 1993). Respondents and key informants reported ill-disciplined and drunken rangers bullying and abusing people, making false accusations in order to demand bribes and extorting money in exchange for 'allowing' illegal grazing and poaching. Similarly, thuggish behaviour of rangers has been reported elsewhere in East Africa (Monbiot, 1994). The programme exposed park staff to community conservation theory and practice, but did not seem to change significantly the behaviour or attitudes of the majority. Relations with communities are still primarily perceived by rangers in terms of conflict, and many interactions and the language used reflect this. Modifying this will require fundamental changes in the recruitment and training of park staff and the gradual building of a new set of norms for the Uganda Wildlife Authority as a whole, from the highest levels of management to the lowest. The progress made amongst communities, their greater ability to differentiate between the acceptable role of rangers as enforcers of national law and the unacceptable behaviour of individual rangers is important. Unless corruption and violence amongst rangers is firmly and transparently dealt with, progress made towards improved relations may be lost.

Changes in community behaviour towards the park and wildlife could not easily be measured. Sensitivity over illegal resource use precluded direct questioning
Table 10 Changes in total impala populations in and around LMNP.

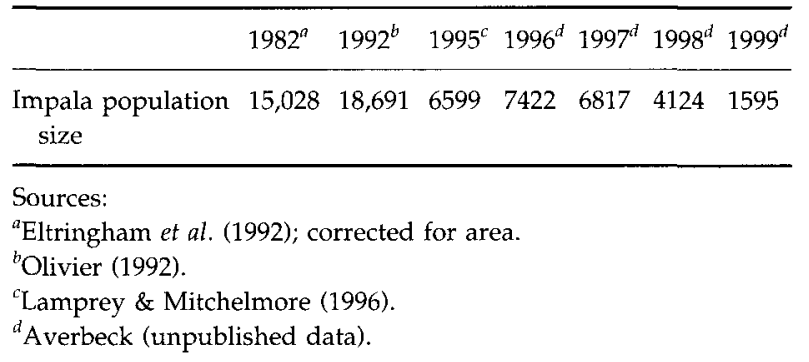

by the questionnaire survey. Qualitative data from key informant interviews and discussions with community members and groups, as well as data from surveys of wildlife populations, suggest that active community support for law enforcement remains low. Although attitudes have changed, behaviour has apparently not. Illegal grazing within the park continues at high levels, and the park authorities receive little support from community members, local leaders or even local government authorities in controlling it.

Aerial surveys carried out over the park and surrounding rangeland show reductions in the populations of large mammals, especially of impala, which are vulnerable to traditional hunting techniques (Table 10). Dramatic contractions in their range outside the park are also shown (Lamprey \& Mitchelmore, 1996; Lamprey, 1996). Indeed, large mammals seem to have largely disappeared from extensive areas outside the park, which they formerly occupied, although suitable habitat remains. Although illegal hunting within the park remains at low levels, largely because of traditional lawenforcement activities, outside the park ${ }^{2}$, it is at unsustainable levels and is largely responsible for the decline in the populations of large mammals. These findings confirm data from earlier studies of illegal hunting and its impact on wildlife (Fraser-Stewart, 1992), and recent information is that land owners are inviting hunters to their land with the specific intention of eradicating it. Park records and anecdotal evidence show that most of the actual hunters come from communities outside the CCP target area and hence have not been influenced by CCP activities. Communities that have benefited from the $\mathrm{CCP}$, however, are not generally reporting the hunting by others and may indeed see the hunters as helpful to their interests.

\footnotetext{
${ }^{2} \mathrm{~A}$ total hunting ban remains in force in Uganda. Promulgated in 1978, it renders all hunting, whether inside or outside protected areas, illegal.
} 


\section{Conclusions}

This paper has examined the effectiveness of a community approach to protected area management. The LMNP has demonstrated the possibility of improving park-community relations, although linking this directly to enhanced conservation status of the park is difficult. It also reveals that community conservation is no easy option, nor an absolute solution to conflicts between protected areas and communities. The considerable improvement in the conservation status of the park, achieved at the same time as community-park relations were improved, however, does suggest that the approach was valuable. The easing of political sensitivities towards the park amongst local leaders and local government that were especially evident in the early 1990s, suggests that the approach was essential.

The cost-effectiveness of the CCP carried out at LMNP is hard to assess. Emerton (1998) quantifies the value of benefits experienced by communities through the programme. Comparison with estimates of cost levied by the park shows a large negative balance. Despite this economic reality, the programme has influenced attitudes, suggesting that creating relatively small benefit flows can improve relations between parks and communities. Research in Tanzania found similar results (Kangwana \& Ole Mako, 1998).

The achievements of the CCP described here are clear, but may be interpreted by some as a meagre return, in either conservation or community development terms, on the time ( 7 years) and money (approximately $\$ U S 2,400,000)$ invested. However, spread over the approximate population of 50,800 residents in the parishes bordering the park (Government of Uganda, 1992) this equates to only $\$ U S 7$ per person per year. Of this sum, 5 per cent went directly into the development of social infrastructure and thus directly impacted community welfare. At the same time, the conservation status of LMNP has been improved significantly, leading to its removal from International Union for Conservation of Nature's (IUCN) list of threatened protected areas.

The full achievement of programmes cannot be demonstrated or measured adequately within their life span. This is especially so where the aim is to translate awareness into changes in behaviour. The rate of progress made at LMNP indicates the need for wildlife authorities and donors to recognize the long-term nature of projects designed to develop and implement community programmes. This is especially so when protected area staff remain more comfortable with traditional 'fines and fences' approaches to managing community issues. Hackel (1999) has commented on the failure of many community conservation projects to make explicit the relationship between efforts to win the support and participation of local communities and law enforcement activities. The contradiction of results showing improving attitudes and continued high levels of illegal resource use to indicate that law enforcement must remain a central aspect of the park's management for the present. Experience at LMNP suggests that community programmes require a solid platform of conventional management to be effective. The balance between conventional and community approaches at LMNP, represented by staff ratios of approximately seven law enforcement to one community ranger (Uganda Wildlife Authority, 1996) indicates, however, that higher levels of support for community conservation will be necessary if the approach is to be given a real opportunity to demonstrate its effectiveness.

The achievements of community outreach are fragile, and easily undone. Undisciplined rangers at LMNP have undermined some of the progress made by the programme. A deeper understanding of the nature of the antagonisms between local people and protected area staff, many of whom are local people themselves, is needed. This will entail a reassessment of the rights and the responsibilities of both sets of protagonists. The organizational culture of conservation agencies must begin to perceive local people as potential partners, not perpetual poachers. Equally, local communities must recognize wardens and rangers as neighbours with a task to achieve, and not simply as corrupt policemen.

\section{Acknowledgements}

Financial support for this research was provided by the Swedish International Development Agency and the United States Agency for International Development. The projects were implemented by the Uganda Wildlife Authority and the AWF. Additional funding was provided by the Biodiversity Support Programme and the British Department for International Development. The staff at LMNP and the communities in which surveys were carried out are thanked for their assistance.

\section{References}

Abrahamson, D. (1983) What Africans think about African wildlife. International Wildlife, 13, 38-41.

Adams, J.S. \& McShane, T.O. (1992) The Myth of Wild Africa: Conservation without Illusion. W.W. Norton, New York.

Adams, W.M. \& Thomas, D.H.L. (1996) Conservation and sustainable resource use in the Gadejia - Jama'are Valley, Nigeria. Oryx, 30, 131-142.

African Wildlife Foundation (1990) Lake Mburo Community Conservation Project Proposal. African Wildlife Foundation, Nairobi.

African Wildlife Foundation (1994) Support for Community Conservation for the Uganda Wildlife Authority with a special 
focus on Lake Mburo National Park:. Project Proposal. African Wildlife Foundation, Nairobi.

Busulwa, H. (1996) Lake Mburo Fisheries Study. Uganda Wildlife Authority, Kampala.

Byers, B.A. (1996) Understanding and Influencing Behaviours in Conservation and Natural Resources Management. African Biodiversity Series, No. 4, Biodiversity Support Program, Washington DC.

Calhoun, J.B. (1991) Plight of the ik. In Resident Peoples and National Parks: Social Dilemmas and Strategies on International Conservation (eds P. C. West and S. R. Brechin), pp. 55-60. University of Arizona Press, Tucson.

Ehrlich, P.R. \& Daily, G.C. (1993) Population extinction and saving biodiversity. Ambio, 22, 64-68.

Eltringham, S.K., Malpas, R.C. \& Tindigarukayo, J. (1992) The Conservation Status of Uganda's Game and Forest Reserves in 1982 and 1983. Unpublished report. Uganda Institute of Ecology, Kampala.

Emerton, L. (1998) Balancing the Opportunity Costs of Wildlife Conservation for Communities around Lake Mburo National Park, Uganda. Community Conservation in Africa: Principles and Comparative Practice. 9. Institute for Development Policy and Management, University of Manchester, Manchester.

Fiallo, E.A. \& Jacobson, S.K. (1995) Local communities and protected areas: attitudes of rural residents towards conservation and Machalilla National Park, Ecuador. Environmental Conservation, 22, 241-249.

Fraser-Stewart, J. (1992) Support for Wildlife and National Parks Management in Uganda. Report. FAO/UNDP, Kampala.

Ghimire, K.B. (1991) Parks and People: Livelihood Issues in National Parks Management in Thailand and Madagascar. Discussion Paper. DP 29. United Nations Research Institute for Social Development, Geneva.

Ghimire, K.B. \& Pimbert, M.P. (1997) Social Change and Conservation: Environmental Politics and Impacts of National Parks and Protected Areas. Earthscan, London.

Government of Uganda (1992) The 1991 Population and Housing Census. Statistics Department, Ministry of Finance and Economic Planning, Entebbe.

Guard, M. (1993) Large Mammals of Lake Mburo National Park: their Population Status and Possible Seasonal Adjustments. Unpublished Report. Uganda National Parks, Kampala.

Hackel, J.D. (1999) Community conservation and the future of Africa's wildlife. Conservation Biology, 13, 726-734.

Hulme, D. \& Infield, M. (1998) Community Conservation in Practice: a Case Study of Lake Mburo National Park, Uganda. Community Conservation in Africa; Principles and Comparative Practice. Discussion Paper No 3. Institute for Development Policy and Management, University of Manchester, Manchester.

Hulme, D. \& Murphree, M. (1999) Communities, wildlife and the 'new conservation' in Africa. Journal of International Development, 11, 11-28.

Infield, M. (1988) Attitudes of a rural community towards conservation and a local conservation area in Natal, South Africa. Biological Conservation, 45, 21-46.

Infield, M. \& Adams, W.M. (1999) Institutional sustainability and community conservation: a case study from Uganda. Journal of International Development, 11, 305-315.

Kamugisha, J.R., Oguta, Z.A. \& Stahl, M. (1997) Parks and People - Conservation and Livelihoods at the Crossroads: Four Case
Histories. Technical Report. 17. Regional Soil Conservation Unit/Swedish International Development Agency (SIDA), Nairobi.

Kamugisha, J.R. \& Stahl, M. (1993) Parks and People; Pastoralists and Wildlife. RSCU Report 7. Regional Soil Conservation Unit/Swedish International Development Agency (SIDA), Nairobi.

Kangwana, K. \& Ole Mako, R. (1998) The Impact of Community Conservation Initiatives around Tarangire National Park, Tanzania (1992-97). Community Conservation in Africa; Principles and Comparative Practice. Discussion Paper no. 16. Institute for Development Policy, Manchester University, Manchester.

Kazoora, C. \& Victurine, R. (1997) The Economics of Community Conservation and Enterprise Development. Unpublished report. African Wildlife Foundation; Uganda Wildlife Authority, Kampala.

Kingdon, J. (1985) Lake Mburo - a new national park in Uganda. Oryx, 19, 7-11.

Lamprey, R. (1996) A Survey of the Wildlife Protected Areas of Uganda; Phase II: April - June 1996. Ministry of Tourism, Wildlife and Antiquities, Kampala.

Lamprey, R.H. \& Mitchelmore, F. (1996) A Survey of the Wildlife Protected Areas of Uganda, September - December 1995: Preliminary Aerial Survey Results and their Assessment Plus Initial Recommendations. Ministry of Tourism, Wildlife and Antiquities, Kampala.

Lewis, D.M. \& Phiri A. (1998) Wildlife snaring - an indicator of community response to a community-based conservation project. Oryx, 32, 111-121.

Mackenzie, J.M. (1987) Chivalry, social Darwinism and ritualised killing: the hunting ethos in Central Africa up to 1914. In Conservation in Africa: People, Policies and Practice (eds D. Anderson and R. Grove), pp. 41-61. Cambridge University Press, Cambridge.

Marquardt, M., Infield, M. \& Namara, A. (1994) Socio-Economic Survey of Communities in the Buffer Zone of Lake Mburo National Park. Lake Mburo Community Conservation Project. Uganda National Parks, Kampala.

Monbiot, G. (1994) No Man's Land: an Investigative Journey Through Kenya and Tanzania. Macmillan, London.

Mugisha, A. (1993) A case study of Nshara Grazing Area, Mbarara, Uganda. MSc Thesis, Wye College, University of London, UK.

Muhweezi, A.B. (1994) The Lake Mburo National Park Management Plan: 1994-98. Uganda National Parks, Kampala.

Murombedzi, J.C. (1999) Devolution and stewardship in Zimbabwe's CAMPFIRE Programme. Journal of International Development, 11, 287-294.

Myers, N. (1996) The rich diversity of biodiversity issues. In Biodiversity II: Understanding and Protecting Our Natural Resources (eds M. L. Reaka-Kudla, D. W. Wilson and E. O. Wilson). National Academy Press, Washington DC.

Namara, A. (1998) Synopsis on Community Conservation Initiatives in Uganda: Report on Consultations among Communities Involved in Community Conservation in Uganda. Unpublished report. African Conservation Centre, Kenya.

Namara, A., Infield M. \& Sumba D. (1998) The Influence of a Community Conservation Programme on Farmers and Pastoralist Communities; Lake Mburo National Park, Uganda. Report of a socio-economic survey carried out under the Community Conservation for Uganda Wildlife Authority Project. Uganda Wildlife Authority, Kampala. 
Naughton-Treves, L. (1998) Prediction patterns of crop damage by wildlife around Kibale National Park, Uganda. Conservation Biology, 12, 156-168.

Noss, A.J. (1997) Challenges to nature conservation with community development in central African forests. Oryx, 31, $180-188$.

Olivier, R. (1992) Aerial Total Counts in Uganda National Parks. Unpublished report. Uganda National Parks, Kampala.

Parry, D. \& Campbell B. (1992) Attitudes of rural communities to animal wildlife and its utilization in Chobe Enclave and Mababe Depression, Botswana. Environmental Conservation, 19, 245-252.

Peluso, N.L. (1993) Coercing conservation? The politics of state resource control. Global Environmental Change, June, 199-217.

Pomeroy, D. \& Kasoma P. (1992) The Birds of Lake Mburo National Park. Lake Mburo Community Conservation Project Report. Uganda National Parks, Kampala.

Ratter, A. (1997). Participatory Evaluation: Community Conservation for Uganda Wildlife Authority Project. Evaluation Report. Community Conservation for Uganda Wildlife Authority Project, Kampala.

Robinson, J.G. (1995) The limits of caring: sustainable living and the loss of biodiversity. In Readings from Conservation Biology; the Social Dimension (ed. D. Ehrenfeld), pp. 138-146. Society for Conservation Biology and Blackwell Science Inc., New York.

Scott, P. (1998) From Conflict to Collaboration: People and Forests at Mount Elgon, Uganda. IUCN, Gland, Switzerland and Cambridge, UK.

Uganda Wildlife Authority (1996) Lake Mburo National Park Reports. Uganda Wildlife Authority, Kampala.

van der Wegge, J.P. (1986) Akagera National Park. World Wildlife Fund International, Gland, Switzerland.

Wells, M.P. (1995) Biodiversity conservation and local development aspirations: new priorities for the 1990s.
In Biodiversity Conservation (eds C. A. Perrings, K. G. Maler, C. Folke and C. Holling), pp. 319-333. Kluwer Academic Publishers, Netherlands.

\section{Biographical sketches}

Mark Infield has worked in wildlife conservation and protected area management in east, central and southern Africa since 1981 . He is interested in the relationship between protected areas and local communities and has worked since 1991 on a community conservation programme in Uganda. He studied zoology at Durham University, and at the University of Natal he examined potentials for creating economic links between game reserves and local communities. He is currently a Research Associate with the African Wildlife Foundation studying for $\mathrm{PhD}$ at the University of East Anglia, looking at the role that culture plays in the conceptualization and management of protected areas and in their potential for building a constituency for conservation amongst rural communities based on local cultural values.

Agrippinah Namara gained her BA (Arts) from Makerere University, Kampala in 1990. Her work at Makerere Institute of Social Research from 1991 led to an interest in natural resource management. She was a team leader for research carried out among communities surrounding Lake Mburo National Park between 1991 and 1997, and has carried out research around other protected areas in Uganda. In 1995 she was awarded her MA (Development Studies) specializing in gender and environment issues from the Institute of Social Studies, The Hague, Netherlands. She is currently a Research Associate at Makerere Institute of Social Research. 